\title{
THE THE AMAZING TECHNOLOGY MEMPERKENALKAN WILAYAH MARITIM DAN POTENSI DAERAH PROVINSI KEPULAUAN RIAU MENGGUNAKAN VISUAL VIDEO DAN BERBASIS ANDROID SEBAGAI MEDIA PENGUATAN PENGETAHUAN ANAK SEKOLAH DASAR DI PESISIR
}

\author{
Deny Nusyirwan ${ }^{1, *}$, Muhammad Bayu Purnama ${ }^{2}$, Muhammad Abyan Fadillah ${ }^{3}$ \\ Prasetya Perwira Putra Perdana ${ }^{4}$, Allysia Shafira ${ }^{5}$, Sulthan Syarif Hanisetya Putra ${ }^{6}$, \\ Dimas Nugroho Putro ${ }^{7}$ \\ 1,2,3,4Fakultas Teknik, Program Studi Teknik Elektro \\ ${ }^{5,6}$ Fakultas Teknik, Program Studi Teknik Informatika \\ Universitas Maritim Raja Ali Haji \\ *Email: denynusyirwan@umrah.ac.id
}

\begin{abstract}
ABSTRAK
Kepulauan Riau (Kepri) adalah provinsi ke-32 di Republik Indonesia yang ditetapkan DPR RI berdasarkan UUD No. 25 dengan Tanjungpinang sebagai ibu kotanya. Menurut Dinas Kesehatan dan Badan Stastistik Kepulauan Riau pada tahun 2016 Provinsi Kepulauan Riau memiliki 253.420 km2 terdiri dari luas lautan 242.825 km2 (96\%) dan luas daratan 10.595,41 km2 (4\%). Dari data tersebut, diharapkan bahwa wilayah pesisir hendaknya mampu menjadi andalan sumber pendapatan masyarakat kepri. Dengan potensi yang unik dan bernilai ekonomi, wilayah pesisir akan menjadi daya tarik terhadap gangguan dan ancaman. Oleh sebab itu perlu dilakukan penguatan sumber daya manusia di wilayah pesisir melalui pendidikan.

Pola kehidupan masyarakat di pesisir yang berbeda tentunya memerlukan pendekatan yang berbeda pula untuk mampu meningkatkan pendidikan dan pengetahuan masyarakat pesisir, adapun solusi yang berbasiskan teknologi yang diusulkan adalah The-AT (The Amazing Technology), untuk memperkenalkan wilayah maritim dan potensi daerah provinsi kepulauan riau menggunakan visual video dan berbasiskan android sebagai media penguatan pengetahuan anak sekolah dasar di pesisir. The AT menerapkan pola permainan untuk anak, yang dimulai dengan permainan menunjukkan peta daerah melalui kamera Gopro sebagai sistem pemantaunya, selanjutnya siswa diminta untuk menyebutkan nama pulau dan lokasi serta potensi daerah tersebut. Android, akan ditampilkan video dan audio mengenai daerah tersebut sebagai informasi kepada siswa yang tidak bisa menjawab dengan benar. Teknologi ini menjadi solusi efektif dalam pembentukan pola fikir untuk anak sekolah dasar mengenai pulau-pulau yang ada di Kepulauan Riau, sehingga terbentuknya rasa mengenal dan rasa ingin membangun potensi yang ada didaerah, yang pada ahirnya akan menumbuhkan calon technopreneur masa depan.
\end{abstract}

Kata kunci: Teknologi, Inovasi, Visual Video, Pola Fikir, Sekolah Dasar, Pulau.

\section{ABSTRACT}

Kepulauan Riau (Kepri) is the 32nd province in the Republic of Indonesia which is determined by the DPRRI based on the Constitution No. 25 with Tanjungpinang as the capital city. According to the Kepulauan Riau Health and Stastistic Agency in 2016 the Kepulauan Riau Province had 253,420 km2 consisting of an ocean area of 242,825 km2 (96\%) and land area of 10,595.41 km2 (4\%). From these data, it is expected that the coastal areas should be able to become a mainstay of the Kepri community's income sources. With the unique potential and economic value, it will be an attraction to disturbances and threats. Therefore, it is necessary to strengthen human resources in coastal areas through education.

The life patterns of coastal communities certainly require a different approach to be able to improve education and knowledge of coastal communities, the technology-based solution proposed is The-AT (The Amazing Technology), introduce the maritime region and the potential of the kepulauan riau using visual video and android as a medium to strengthen the knowledge of elementary school children on the coast. The-AT applies games for childrens, which begins with the game showing a map of the area through a gopro camera, then the 
students are asked to name the island and the location and potential commodities of the area. Android, video and audio will be displayed about the area as information to students who cannot answer correctly. This technology is an effective solution in the formation of thinking patterns for elementary school children regarding the islands in the Kepulauan Riau, so that the formation of a sense of familiarity and a sense to build the potential that exists in the area. At the end it will initiate the technopreneur in the future.

\section{Keywords: technology, innovation, visual video, mindset, elementary school, island}

\section{PENDAHULUAN}

Seiring dengan semakin berkembangnya industri juga telah diikuti dengan meningkatnya limbah hasil produksi, apabila hal ini tidak diperhatikan maka akan dapat mengakibatkan pencemaran lingkungan. Tercemarnya lautan dengan limbah yang mengandung logam dapat mengakibatkan jumlah organisme yang hidup di laut semakin berkurang dan bahkan akan habis (Goldberg, 1995), permasalahan ini secara langsung akan dapat mengurangi hasil tangkapan nelayan sehingga pendapatan dari hasil melaut tidak akan mampu untuk menopang kehidupan keluarganya. Apabila kejadian ini terjadi secara terus menerus, maka akan dapat mengakibatkan kemiskinan pada masyarakat nelayan di pesisir. Program pemerintah untuk menekan kemiskinan dan meningkatkan perekonomian masyarakat adalah dengan memberdayakan masyarakat setempat, dengan meningkatkan pengetahuan mengenai potensi setempat melalui pelatihan-pelatihan yang selanjutnya dapat dipergunakan untuk meningkatkan penghasilan. Selain usaha tersebut, juga bantuan pendanaan kepada masyarakat nelayan untuk membina ataupun mengembangkan usaha yang sedang dikerjakan (Cahaya, 2015). Sedangkan untuk pendidikan di pesisir, diketahui masih tingginya tingkat putus sekolah, hal ini disebabkan oleh pola kehidupan masyarakat di pesisir yang berbeda, dimana anak lelaki yang sudah cukup dewasa akan cenderung membantu bapak melaut dan anak perempuan membantu ibu untuk di kebun. Selain itu, cukup puas dengan penghasilan yang pasti sebagai seorang nelayan, dimana untuk mendapatkan penghasilan tanpa harus membutuhkan ijazah atau legalitas dari akademika. Adalah merupakan tantangan tersendiri bagi pelaku di bidang pendidikan untuk menawarkan sebuah pola pendidikan yang tepat bagi masyarakat nelayan pesisir. (Masri, 2017). Karena tingkat pendidikan masyarakat yang rendah, pada ahirnya masyarakat juga akan memliliki pengetahuan yang rendah pula sehingga akan sulit untuk melakukan perubahan mendasar terkait pola pikir, kebiasaan, pola hidup dan analisis, sehingga teknologi dan bantuan modal yang diberikan oleh pemerintah nantinya tidak akan mampu dimanfaatkan. Hal ini tentu akan dapat mengakibatkan dampak yang sangat buruk bagi kehidupan masyarakat pesisir kedepannya.

Untuk mengatasi hal tersebut, diperlukan sebuah pendekatan yang berbasis pengguna yang dimulai dengan observasi di masyarakat nelayan kampung bugis kota tanjung pinang, menentukan permasalahan utama untuk bidang pendidikan, menentukan solusi utama dan pembuatan purwarupa sederhana untuk ujicoba dengan calon pengguna agar menghasikan sebuah inovasi yang merupakan solusi bagi permasalahan di masyarakat setempat.

Adapun solusi dari permasalahan pendidikan di daerah pesisir kampung Bugis adalah sebuah metode pembelajaran berbasiskan Android dengan menngunakan teknologi Augmented Reality (AR) untuk anak sekolah dasar yang bernama The-AT (The Amazing Technology), AR menggabungkan dimensi dunia nyata dengan dimensi dunia nyata yang termediasi atau dunia virtual untuk menciptakan kesan bahwa dimensi dunia nyata adalah objek tiga dimensi, pemanfaatan AR untuk mengedukasi anak akan memberikan pandangan baru terhadap media edukasi yang ada pada saat ini, bukan hanya menggunakan objek secara nyata tapi juga bisa digunakan objek berbentuk virtual dalam penyampaian informasi. Nilai tambah dari media ini adalah mempermudah penyampaian dan membuat informasi semakin menarik terutama bagi anak (Hidayat, 2015). Selain itu, kemampuan akademis siswa yang mempergunakan AR akan mampu melebihi siswa dengan menggunakan metode tradisional (Bursali, 2019 dan Cieza, 2018) . AR juga akan mampu menyampaikan informasi lebih baik (Chih-Ming, 2012), dan dapat menjadi media untuk mengembang sosial dan emosional anak melalui permainan (Hasanah, 2016). The AT bertujuan untuk memperkenalkan wilayah maritim dan potensi daerah di Provinsi Kepulauan Riau (Kepri) sehingga mampu menumbuhkan semangat untuk membangun potensi 
yang ada didaerah tersebut, serta meningkatkan kemampuan belajar dan motivasi siswa dengan memanfaatkan teknologi digital penerapan teknologi AR dalam proses pembelajaran.

\section{KAJIAN PUSTAKA}

Didalam penelelitian ini, telah di lakukan kajian terhadap penelitian terdahulu yang akan di pergunakan sebagai batasan terhadap penelitian yang akan di lakukan, selain itu kajian pustaka juga akan menjelaskan mengenai cara kerja purwarupa

\subsection{Penelitian terdahulu}

Pada penelitian yang berjudul "Virtual and Augmented Reality Technologies for Product Realization" menjelaskan mengenai penerapan AR di perusahaan untuk meningkatkan kinerja perusahaan dan menghasilkan produk yang sukses. Realisasi produk adalah salah satu tantangan utama dalam profesi teknik, oleh sebab itu diperlukan interaksi yang baik antara komputer dan desainer. Adapun sistem yang diterapkan adalah dengan menggunakan helm, sehingga desainer akan mampur berinteraksi dengan produk yang sedang di rancang (Lu, 1999)..Sedangkan penelitian yang berjudul "The application of augmented reality technologies for the improvement of occupational safety in an industrial environment" merupakan penerapan AR pada industri untuk mengurangi terjadinya kecelakaan. Pekerja akan mendapatkan Tablet PC yang dipergunakan untuk menampilkan prosedur kerja dan tata cara untuk mengoperasikan mesin dengan benar melalui AR (Tatića, 2017). Sila lihat pada Gambar 1

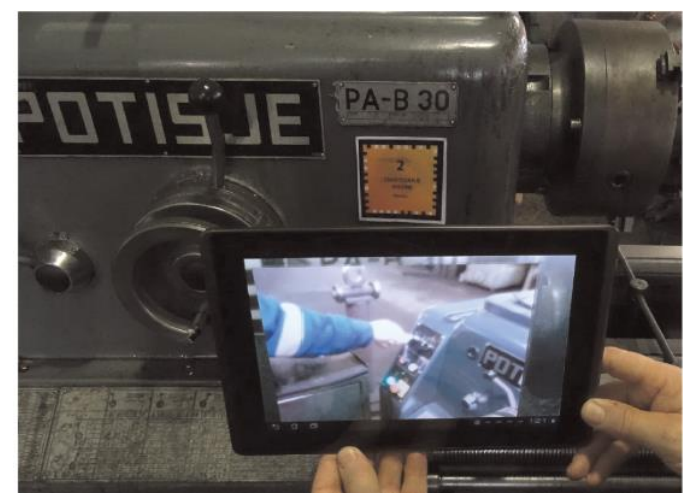

Gambar 1. Tablet PC yang dipergunakan untuk menampilkan prosedur kerja

Adapun pada Penelitian yang berjudul "Visual Assembling Guidance Using Augmented Reality" adalah penelitian yang memanfaatkan AR pada jalur perakitan di perusahaan, metode ini akan mampu untuk memberikan panduan visual kepada pekerja ketika akan merakit produk. Pada ahir penelitian dapat disimpulkan bahwa penggunaan AR dapat di prioritaskan kepada pekerjaan yang tingkat kesulitannya cukup tinggi (Syberfeldt, 2015). Tugas perakitan yang digunakan dalam penelitian ini terdiri dari menyusun puzzle tiga dimensi dengan Sembilan potongan, sila lihat pada Gambar 2. Potonganpotongan tersebut harus ditempatkan dalam urutan tertentu dan pada posisi tertentu, seperti dalam perakitan industri. Tugas ini relatif sederhana dibandingkan dengan perakitan industri dunia nyata, penelitian ini tidak bertujuan untuk menilai efektivitas yang diperoleh dengan AR, melainkan untuk menyelidiki penerimaan teknologi AR pada pekerja.
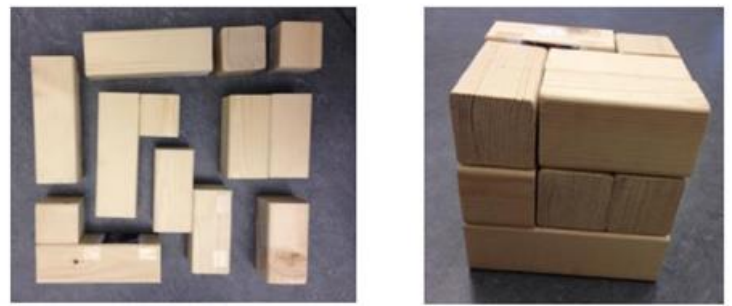

Gambar 2. Puzzle tiga dimensi dengan Sembilan potongan

\subsection{Landasan Teori}

Pentingnya penggunaan Audio Visual didalam mendukung pembelajaran siswa di pesisir saat ini dan kedepannya, tentunya juga akan memerlukan desainer yang mampu merancang inovasi berbasiskan teknologi yang sesuai dengan kebutuhan didalam kegiatan belajar di sekolah (Kesima, 2012). The AT (The Amazing Technology) merekam seluruh bagian peta yang sudah di sediakan dalam sebuah bentuk purwarupa. Dengan menggunakan kamera Gopro sebagai sistem pemantaunya, selanjutnya pengamatan juga tersambung dengan Android sebagai metode visual video peta dalam pembelajaran anak sekolah dasar. Sila lihat pada Gambar 3.

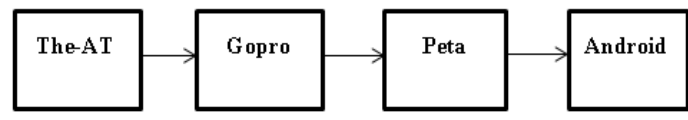

Gambar 3. Tahapan Cara Kerja The-AT (The Amazing Technology) 
The-AT (The Amazing Technology) adalah alat yang diperkenalkan oleh anak-anak sebagai hasil akhir dalam permaianan kartu yang sudah dicetak dengan gambar-gambar kabupaten dan kota di wilayah provinsi kepri sebagai tanda kartu yang akan dimainkan. Sila lihat pada Gambar 4.

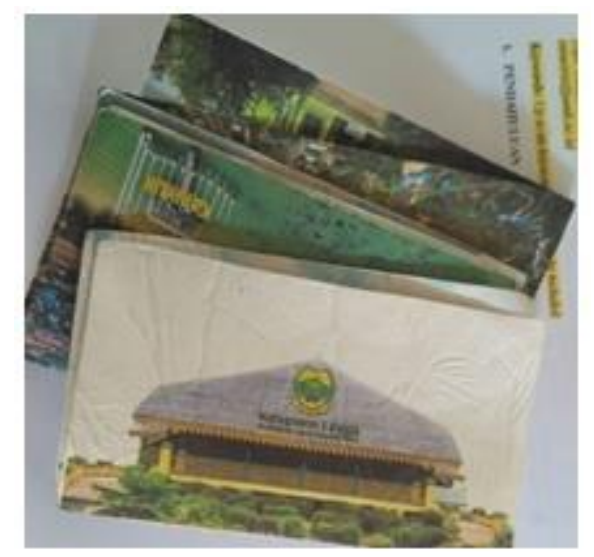

Gambar 4. Kartu yang telah disiapkan dalam permainan.

Cara mainnya adalah anak sekolah dasar cukup menebak salah satu pulau yang sudah disusun, maka langkah selanjutnya kartu tersebut akan menjadi salah satu wilayah yang dikuasai oleh sang anak. Jika anak sekolah dasar salah dalam menjawab pertanyaan dari teman-temannya yang menyimpan kartu yang sama dari berbeda wilayah, maka permainan ini akan menerapkan sistem kalah untuk wilayah yang di jagokan. Sila lihat pada Gambar 5. Yang menampilkan struktur perrmainan.

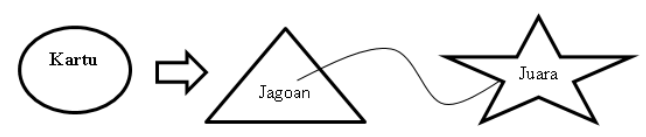

Gambar 5. Struktur Permainan

Teknologi yang dipergunakan dalam edukasi pembelajaran adalah Augmented Reality (AR), untuk menumbuhkan minat anak sekolah dasar dalam ilmu pengetahuan dan buku panduan sebagai pedoman permainan nantinya. AR akan mendukung peran pada permainan tebak kartu, dan sangat berperan penting dalam kelanjutan pembentukan pola fikir untuk anak sekolah dasar dengan menampilkan secara detail berapa jumlah kecamatan, potensi, dan daerah yang dipilih. AR diterapkan dengan scanner logo wilayah masing-masing. AR berperan untuk meyakinkan anak sekolah dasar pada jawaban mereka, dirancang menggunakan visual video sebagai sarana tepat untuk memahami jawaban permainan. AR juga menjadi salah satu keunggulan The-AT untuk menuju Revolusi Industri 4.0.

Buku panduan menjadi sarana pemahaman teori dasar pada anak. Diterapkan sebelum permainan dimulai, sepertinya yang dijelaskan sebelumnya bahwa buku panduan dapat menjadi salah satu pemahaman anak dalam The-AT. Didalam Buku panduan terdapat logo daerah/wilayah yang akan di scanner untuk menampilkan AR nantinya. Adapun logo daerah tersebut adalah Kabupaten Bintan, Kabupaten, Kabupaten, Kabupaten, Kota Tanjungpinang, Kota Batam dan Kabupaten Anambas dengan Ibu kota Tarempa. Sila lihat pada Gambar 6.
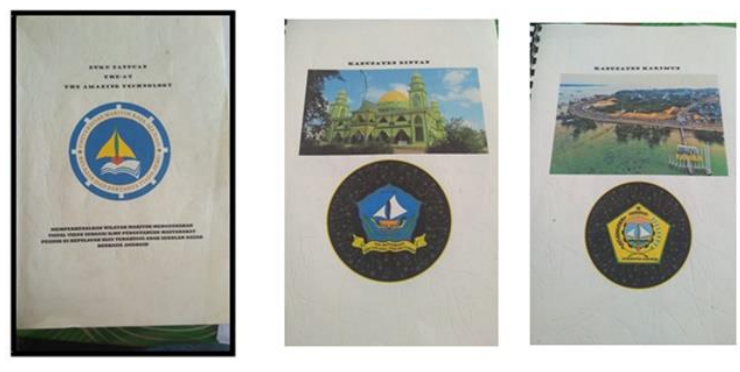

Gambar 6. Buku panduan dengan logo daerah untuk dibaca oleh scanner

\section{ANALISA DAN PEMBAHASAN}

\subsection{Observasi}

Observasi dilakukan pada tanggal 22 maret hingga 29 maret 2019 sebagai bentuk pehamanan kondisi wilayah dan lingkungan sekolah yang menjadi objek dalam pengamatan ilmu pengetahuan. Observasi ini dilakukan di SDN 005 Kampung Bugis sebagai bentuk pelatihan dan sosialisasi pengenalan teknologi dalam agenda KPM Community. Setelah delapan hari melewati masa pelatihan, maka didapat data berjumlah 100 tanggapan dalam presentase ilmu pengetahuan yang sudah dirangkum melalui survei daring google form.. Untuk mendapatkan data tersebut telah diajukan beberapa pertanyaan mengenai Kepulauan Riau beserta pulau-pulau besar yang mencakup metode dasar pembentukan pola fikir.

Dapat dilihat pada Gambar 7., Sekitar 30\% anak sekolah dasar di SDN 005 Kampung Bugis 
memahami sedikitnya wilayah maritim tersebut, memahami pulau-pulau yang berada di kepulauan Riau, tetapi tidak untuk potensinya. Kemudian $70 \%$ anak sekolah dasar tidak sama sekali mengetahui pulau-pulau tersebut dan hanya berdiam tidak menjawab. Dengan demikian perlunya langkah untuk membentuk pola fikir mereka selanjutnya

100 tanggapan

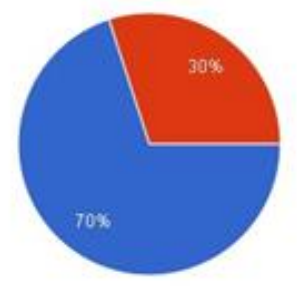

Gambar 7. Hasil Survey Daring melalui google form

\subsection{Purwarupa Sederhana}

Tahapan pembuatan Purwarupa adalah tahapan yang sudah mulai memerlukan pembiayaan. Oleh sebab itu pada proses ini, menekankan untuk mampu menghasilkan Purwarupa sederhana yang ekonomis dan fleksible, dengan maksud bahwa perubahan rancangan dapat dilakukan dengan mudah dan tidak akan memerlukan pembiayaan yang besar. Purwarupa dalam tahapan ini lebih dikenal dengan istilah purwarupa sederhana (Nusyirwan, 2017). Dapat dilihat pada gambar adalah sebuah Purwarupa sederhana The AT, sila lihat Gambar 7.

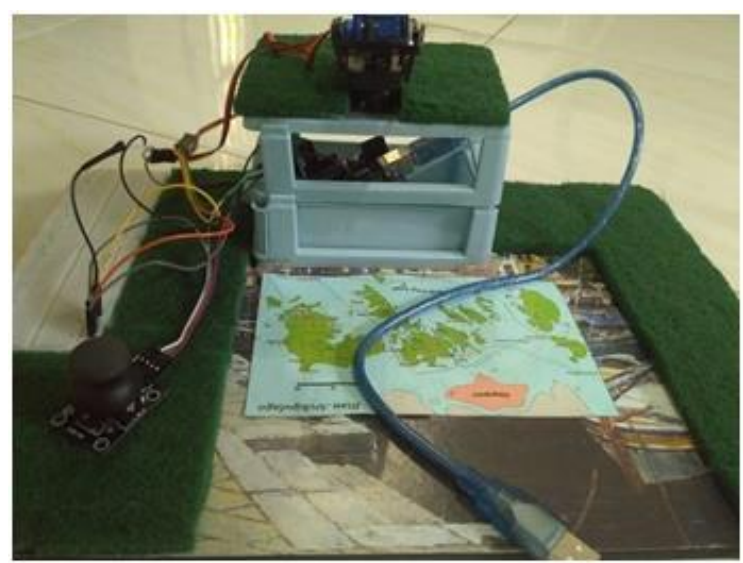

Gambar 7. Purwarupa sederhana yang disiapkan untuk uji coba ke pengguna
Pada Gambar 8 menampilkan skematik diagram pada The AT. The AT menggunakan mikrokontroler arduino UNO untuk mengontrol perangkat atau komponen elektronika yang di program sesuai dengan pemanfaatan The-AT, menggunakan komponen 2 buah servo dengan radius putar maksimal 180 derajat dan menggunakan joystick 2 axis atau 1 variable $\mathrm{X}$ dan $\mathrm{Y}$, dapat dilihat pada rangkaian skematik diatas dua servo tersebut di control oleh joystick sehingga kedua servo tersebut dapat di putar ke arah mana yang kita mau, fungsi servo pertama ialah untuk putaran kearah bagian atas dan bawah sedangkan untuk servo yang kedua untuk putaran kearah samping kiri dan samping kanan. Adapun komponen pendukung dari The AT ini ialah chasis pant tilit untuk kedudukan kamera, jadi kedua servo tersebut dapat menggerakan kamera kearah yang kita tuju, untuk ruang lingkup pada kamera tersebut di fungsikan untuk menampilkan gambar di peta dan gambar yang di tangkap di kamera tersebut di koneksikan dengan smartphone dan kita dapat melihat gambar yang dihasilkan kamera tersebut di smartphone secara real time. Sehingga kedua servo dan joystick tersebut berfungsi untuk mengontrol arah putar pada kamera tersebut.
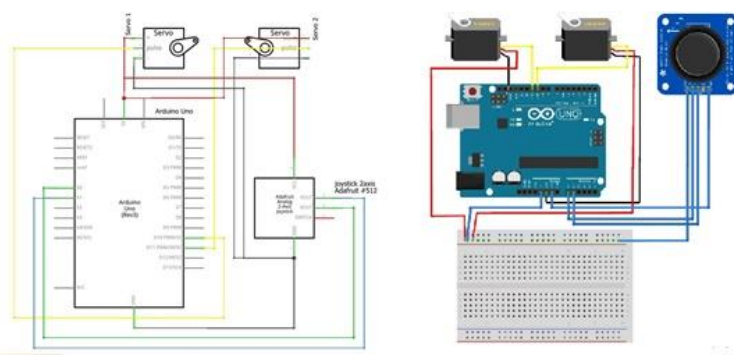

Gambar 8. Skematik dan Breadboard Diagram pada The AT

\subsection{Purwarupa Sederhana}

Pengujian kegunaan adalah proses evaluasi terhadap inovasi yang dirancang dengan berbasis pengguna. Pada tahapan ini pengguna akan berpartisipasi dan berinteraksi secara langsung dengan Purwarupa sederhana yang dihasilkan dari proses sebelumnya. Pengguna akan diminta untuk melakukan tugas tertentu atau hanya menjelajahinya secara bebas, sementara perilaku pengguna diamati dan dicatat untuk mengidentifikasi kelemahan desain yang menyebabkan kesalahan atau kesulitan pengguna. Selama pengamatan ini, Setelah kelemahan desain telah diidentifikasi, rekomendasi desain diusulkan untuk meningkatkan kualitas ergonomis produk 
Peranan penting bagi ilmuwan pada abad ke21 adalah berperan serta dalam mendidik masyarakat tentang metode dan hasil proses ilmiah (Kastner, 2017), oleh sebab itu diperlukan inovasi berbasiskan teknologi yang memiliki fungsi yang tepat untuk penguatan pendidikan di wilayah pesisir. Dengan The AT, diharapkan masyarakat pesisir di wilayah Kepri akan termotivasi untuk belajar dan mengenal potensi wilayahnya sehingga akan mampu membangun daerah nya dan menjaga dari ancaman.

\subsection{Saran}

Pola kehidupan masyarakat di pesisir yang berbeda memerlukan pendekatan yang berbeda pula untuk mampu meningkatkan pendidikan dan pengetahuan masyarakat pesisir, oleh sebab itu diperlukan kerjasama antara perguruan tinggi dan pemerintah yang lebig erat.

Selain itu, peningkatan pelatihan-pelatihan bidang rekayasa yang dimulai dari tingkat sekolah dasar di kota tanjungpinang provinsi Kepulauan Riau (KEPRI) untuk menginisiasi calon Technopreneur dan ilmuwan dimasa depan yang mampu merealisasikan hasil penelitian berupa teknologi guna meningkatakan perekonomian masyarakat pesisir

\section{UCAPAN TERIMA KASIH}

Terima kasih kepada civitas akademika di jurusan teknik elektro dan informatika Universitas Maritim Raja Ali Haji (UMRAH) dan redaksi JURNAL TECHNOPRENEUR POLITEKNIK GORONTALO yang telah memberikan kesempatan untuk publikasi

\section{ACUAN REFERENSI}

Bastien, M., C., (2010) "Usability testing: a review of some methodological and technical aspects of the method", International Journal of Medical Informatics, Volume 79, Edisi 4, hal e18-e23, Elsevier Ireland Ltd

Bursali, H., Yilmaz, R., M., (2019). "Effect of augmented reality applications on secondary school students' reading comprehension and learning permanency", Computers in Human Behavior, Vol. 95, hal 126-135, Elsevier Ltd

Cahaya, A., (2015). "Fishermen Community in the Coastal Area: A Note from Indonesian Poor Family", Procedia Economics and Finance 26 , hal $29-33$.
Chih-Ming, C., Yen-Nung, T., (2012) “Interactive augmented reality system for enhancing library instruction in elementary schools", Computers \& Education, Vol. 59, Issue 2, hal. 638-652, Elsevier Ltd

Cieza, E., and Lujana, D., (2018). "Educational Mobile Application of Augmented Reality Based on Markers to Improve the Learning of Vowel Usage and Numbers for Children of a Kindergarten in Trujillo", Procedia Computer Science. Vol. 130, Hal. 352-358 Elsevier B.V

Goldberg, E., D., (1995). "Emerging problems in the coastal zone for the twenty-first century", Marine Pollution Bulletin Volume 31, Issues 4-12, hal 152-158, Elsevier Ltd.

Hasanah, E., U., (2016). Permainan Dengan Media Informasi Dan Teknologi (IT) Dalam Mengembangkan Sosial Emosional Anak. Skripsi. Universitas Muhammadiyah Surakarta.

Hidayat, T., (2015). "Penerapan Teknologi Augmented Reality Sebagai Model Media Edukasi Kesehatan Gigi Bagi Anak", Citec Journal, Vol. 2, No. 1. Teknik Informatika STMIK AMIKOM Yogyakarta

Kastner, S., and Knight, R., T., (2017). "Bringing Kids into the Scientific Review Process", Neuron Volume 93, Edisi 1, hal 12-14, Elsevier Inc

Kesima, K., Ozarslan,Y., (2012). “Augmented Reality in Education: Current Technologies and the Potential for Education", Procedia Social and Behavioral Sciences Vol. 47, hal 297-302, Elsevier Ltd

Lu, S., C-Y., Shpitalni, and M., Gadh, G., (1999). "Virtual and Augmented Reality Technologies for Product Realization", CIRP Annals, Vol. 48, Issue 2, hal 471-495, Elsevier B.V

Masri, A., (2017). Pendidikan Anak Nelayan Pesisir Pantai Donggala, Asian Journal of Environment, History and Heritage, Vol. 1, Issue. 1, hal. 223-227, Institute of the Malay World and Civilization

Nusyirwan, D., (2017). Engineering Design Process Engineering Student Centered Experience Learning (ESCEL) di Jurusan Teknik Elektro Universitas Maritim Raja Ali Haji (UMRAH), Jurnal Sustainable Vol. 06, No. 01, hal. 24-35. 
Syberfeldt, A., Danielsson, O., Holm, M., and Wang, L., (2015) "Visual Assembling Guidance Using Augmented Reality", Procedia Manufacturing, Volume 1, hal 98-109, Elsevier B.V.

Tatića, D., and Tešićb, B., (2017). "The application of augmented reality technologies for the improvement of occupational safety in an industrial environment", Computers in Industry Vol. 85, hal 1-10, Elsevier B.V 